\title{
Sensory, Physico-Chemical, Textural and Microbial Changes in Milk Protein Concentrate and Cereal Based Energy Bar during Storage
}

\author{
Karmajitsinh Jagadevsinh Jetavat ${ }^{1}$, Amitkumar Manojbhai Patel ${ }^{2 *}$ \\ and Smitha Balakrishnan ${ }^{2}$ \\ ${ }^{1}$ Banas Dairy, Faridabad, India \\ ${ }^{2}$ SMC College of Dairy Science, AAU, Anand, India \\ *Corresponding author
}

\begin{abstract}
A B S T R A C T
Keywords

Milk Protein

Concentrate,

Energy bar, Oats,

Ragi, Rice

Article Info

Accepted:

08 June 2020

Available Online:

10 July 2020

Energy bar are gaining recognition as well as appreciation these days due to their ready-to- eat nature, delicious taste, nutritional profile and appealing look. Cereals play an important role in human diet and nutrition. Protein quality of cereals can be improved by combining it with other rich sources like milk protein. The milk solids (milk protein concentrate) and cereal based energy bar (MCEB) and control energy bar were stored at cabinet temperature $\left(15 \pm 2^{\circ} \mathrm{C}\right)$ after packaging them in metallized PET Polyester/ Polyfilm pouches material. The MCEB samples were analyzed for changes in sensory characteristics, physico-chemical characteristics, textural characteristics as well as for microbiological quality at 15 days interval. Sensory scores and fracturability for experimental sample and control decreased while peroxide value, free fatty acids, water activity and hardness increased during entire storage period. The Standard plate count decreased while coliform count and yeast and mold count were found absent till 150 days of storage.
\end{abstract}

\section{Introduction}

Cereals play an important role in today's lifestyles for their various uses as ready-to-eat products, instant products, cereal bars and energy bars. The consumption of cereals has been elaborated from the breakfast table to any time of the day and these products have become an integral part of consumer's diet (Berti et al., 2005). Demand for the processed and convenience foods is increasing rapidly due to the increasing awareness about the health, changing socio-economic needs, and insufficient time to cook food with the correct/ balanced amount of nutrition. One such nutritionally balanced convenience food is the nutritious energy bars, which are gaining popularity in the global market after 1980s.

Earlier, these energy bars were used by the sport persons who were involved in strong physical activities and therefore, needed greater source of energy during peak 
performance. But today, due to the increasing focus on the nutrition and healthy food habits and an increasing number of people involved in greater physical activities, energy bars have become a perfect choice as a quality source of energy. These energy bars are prepared in the form of tablets either using compression technology or using different binders of choice. The bars contain wide range of nutrients as well as sufficient amount of proteins, fats, and carbohydrates and are available in smaller packets or pouches, light in weight, very convenient to carry and can be eaten at any point of time. There are different types of energy bars referred by different names such as protein bars, meal replacement bars, granola bars, nutraceutical bars, breakfast bars, health bars and so on. Each bar has different characteristic with a different purpose (Sharma, 2011). The new trend for consumption of healthy, innovative and practical food, which has occurred recently, has lead the market of cereal-bars to a gradual growth. Cereal bars are considered healthy type of food, because they are rich in fibre, however, poor in fat (Bower and Whitten, 2000; Palazzolo, 2003). Cereal bars are products obtained from the compression of cereals, containing dried fruits, nuts, flavorings and binder ingredients. Ingredients usually contained in cereal bars are mixtures of cereals, pulses, milk solids, dried fruit, nuts, corn syrup, honey, sugar, lecithin and flavourings (Karam et al., 2001).

\section{Materials and Methods}

\section{Raw materials}

Good quality rice and ragi flour were procured from local market of Anand. Rice and ragi crispies were prepared from these flour individually in the co-rotating twin screw extruder. Malt extract was procured from J.K. Malt Products Pvt. Ltd, Nadiad, Gujarat, India. Milk Protein Concentrate
(MPC) containing 80 per cent protein was procured from Dindigul Farm Product Pvt. Ltd., Dindigul, Tamilnadu, India. Rolled oats (Kelloggs brand) and honey (Dabur brand) were brought from the authorized dealer of Anand town. Table butter (Amul brand) was brought from the authorized dealer of Anand town. Milk chocolate slabs and liquid glucose were procured from Kaira District Cooperative milk Producers' Union Ltd., Anand. Fine crystalline sugar of Madhur brand was brought from the authorized dealer of Anand town. Good quality sesame seeds and almonds were procured from local market of Anand. The emulsifier used in this study was soy Lecithin supplied by $\mathrm{Hi}$ Media Laboratories Pvt. Ltd., Mumbai. Food grade sodium bicarbonate (NaHCO3) of TATA brand was used as a leavening agent in Energy bar.

\section{Equipment / instruments}

The equipment and instruments used in the present study are detailed below:

Equipment used in the present study included hot air oven (Model No. IK-III, IKON, India), analytical balance (Sartorius, England), vortex mixture (SAIF Surgical \& Scientific Equipment, Gujarat), muffle furnace (Model No. EIE-500 $(5 \mathrm{~kW}), \quad$ Erection \& Instrumentation Engineers, Ahmedabad, India), water activity meter (Hygrolab 3, Rotronic Measurement Solutions AG, Switzerland), texture analyser (Stable Micro Systems, UK), co-rotating twin screw extruder (BTPL lab model, Basic Technology Pvt. Ltd. Kolkata, India).

\section{Glasswares}

All glassware used in the study were of standard quality supplied by Borosil and Jain Scientific Glass Works (JSGW), India. In case of specific experiment, the calibrated 
glassware as specified by Bureau of Indian Standards were used.

\section{Chemicals}

All the chemicals used in the preparation of different reagents were of analytical grade (AR) and were procured from standard companies. The reagents required for analysis were freshly prepared adopting standard procedures.

\section{Packaging materials}

The product after chocolate coating was packed in laminates of Metallised Polyethylene Terephthalate (METPET)Polyester/Polyfilm pouches $(\sim 85 \quad \mu \mathrm{m}$ thickness) and the packets were stored at $15 \pm 2^{\circ} \mathrm{C}$.

\section{Manufacture of MPC and cereal based energy bar}

Preliminary trials were carried out for selection of various dry ingredients such as MPC-80, rolled oats, ragi crispies, rice crispies, almonds, sugar and sesame seeds. Rolled oats, almonds and sesame seeds were roasted individually in a stainless steel pan before blending into dry ingredients mix. Initially, trials were conducted for standardizing the level of roasted rolled oats, roasted almonds, roasted sesame seeds, table butter and malt extract. As per preliminary trials and available literature, the proportion of rolled oats, almonds, sesame seeds, table butter and malt extract were kept constant as 10 per cent, 5 per cent, 3 per cent, 10 per cent and 5 per cent respectively in the final formulation of MCEB (Milk solids and cereal based energy bar). Central Composite Rotatable Design (CCRD) (four factor response surface methodology, RSM) was used to optimize the proportion of levels of rice to ragi crispies ratio, MPC-80, liquid glucose and honey. Emulsifier (Soy Lecithin) and leavening agent (Sodium bicarbonate/Baking soda) were added in the proportion of 0.2 per cent and 0.5 per cent, respectively. Sugar was added by difference so that the final formulation of MCEB becomes 100 per cent.

Dry ingredients viz. MPC-80, roasted rolled oats, rice crispies, ragi crispies, roasted almonds, roasted sesame seeds, sugar, lecithin and Sodium bicarbonate were weighed as per their rate of addition (either constant or as suggested by RSM). Wet ingredients such as malt extract, liquid glucose, table butter and honey were weighed as per their rate of addition (either constant or as suggested by RSM) and heated to $95^{\circ} \mathrm{C}$ to form a syrup. The pre-weighed dry ingredients were mixed with the heated syrup and mixed thoroughly. The mixture of dry and wet ingredients were then poured in pre-greased aluminium baking trays. The tray containing mixture was transferred to pre-heated oven and was baked at $150^{\circ} \mathrm{C}$ for 20 minutes. After baking the content was allowed to cool at room temperature and then cut into rectangular pieces (approximate weight of each bar was $25 \mathrm{~g}$ ). The cut energy bars were further cooled to $-15^{\circ} \mathrm{C}$ for $1.5 \mathrm{~h}$ and then dipped into melted milk chocolate (melting temperature of chocolate was maintained at $40^{\circ} \mathrm{C}$ ) to form a chocolate layer around the energy bar. The chocolate coated milk solids and cereal based energy bar (MCEB) were then packaged into laminates of Metallised Polyethylene Terephthalate (METPET) Polyester/Polyfilm pouches $(\sim 85 \mu \mathrm{m}$ thickness $)$ and the packets were stored at cabinet temperature $\left(15 \pm 2^{\circ} \mathrm{C}\right)$.

\section{Results and Discussion}

The behaviour of milk solids and cereal based energy bar (MCEB) as like other dairy/food products during storage is crucial for its commercial success. Shelf-life of the product 
is most important from manufacturing and consumer point of view. The milk solids and cereal based energy bar T2 and control energy bar sample $\mathrm{T} 1$ were stored at cabinet temperature $\left(15 \pm 2^{\circ} \mathrm{C}\right)$ after packaging it in metallized PET Polyester/Polyfilm pouches ( $\sim 85 \mu \mathrm{m}$ thickness) material. The MCEB samples were analyzed for changes in sensory characteristics, physico-chemical properties, and textural characteristics as well as for microbiological quality at 15 days interval.

Changes in the sensory characteristics of milk solids (milk protein concentrate) and cereal based energy bar during storage

The changes in sensory characteristics of samples T1 and T2 packed in metallized PET Polyester/ Polyfilm pouches and stored at cabinet temperature $\left(15 \pm 2^{\circ} \mathrm{C}\right)$ is shown in the Table 1.

The flavour score of $\mathrm{T} 1$ and $\mathrm{T} 2$ decreased from 7.94 and 8.55 on zero day to 5.46 and 5.97 respectively at the end of 150 days of storage at cabinet temperature $\left(15 \pm 2^{\circ} \mathrm{C}\right)$. The changes in the flavour scores of the treatments (T1 and T2) and interaction effect between the treatments and periods were significant. This shows that there was significant effect of change in formulation on storage stability of product with respect to flavour characteristics.

The flavour scores of control energy bar T1 decreased below 7.0 (which stands for like moderately on 9- point hedonic scale) after 90 days of storage while that of milk solids and cereal based energy bar T2 decreased below 7.0 after 120 days of storage at $15 \pm 2^{\circ} \mathrm{C}$. But the flavour score of both the T1 and T2 were less than 6.0 (which stands for like slightly on 9-point hedonic scale) on $150^{\text {th }}$ day of storage.

The body and texture score of T1 and T2 decreased from 7.94 and 8.47 on zero day to 5.57 and 5.99 respectively at the end of 150 days of storage at cabinet temperature $\left(15 \pm 2^{\circ} \mathrm{C}\right)$. The changes in the body and texture scores among the treatments $\mathrm{T} 1$ and $\mathrm{T} 2$ and the interaction effect between the treatments ( $\mathrm{T} 1$ and $\mathrm{T} 2$ ) and periods were significant. The body and texture scores of both T1 and T2 decreased below 6.0 (which stands for like slightly on 9-point hedonic scale) after 135 days of storage at $15 \pm 2^{\circ} \mathrm{C}$.

The colour and appearance score of $\mathrm{T} 1$ and T2 decreased from 8.16 and 8.52 on zero day to 5.32 and 5.98 respectively at the end of 150 days of storage at cabinet temperature $\left(15 \pm 2^{\circ} \mathrm{C}\right)$.

The changes in the scores of colour and appearances among the treatments as well as the interaction effect between the treatments (T1 and T2) and periods were significant. The colour and appearance scores of both T2 and T1 decreased below 6.0 (which stands for like slightly on 9-point hedonic scale) after 135 days of storage at $15 \pm 2^{\circ} \mathrm{C}$.

The overall acceptability score of $\mathrm{T} 1$ and $\mathrm{T} 2$ decreased from 7.65 and 8.53 on zero day to 5.22 and 5.92 respectively at the end of 150 days of storage at cabinet temperature $\left(15 \pm 2^{\circ} \mathrm{C}\right)$. The changes in the scores of overall acceptability among the treatments (T1 and T2) and the interaction effect between the treatments and periods were significant for overall acceptability. The overall acceptability scores of $\mathrm{T} 2$ and $\mathrm{T} 1$ decreased below 6.0 (which stands for like slightly on 9-point hedonic scale) after 135 days of storage storage at $15 \pm 2^{\circ} \mathrm{C}$.

The overall acceptability score of milk solids and cereal based energy bar $\mathrm{T} 2$ was below 6.0 on $150^{\text {th }}$ day of storage at $15 \pm 2^{\circ} \mathrm{C}$, so the storage study was discontinued after 150 days. Based on sensory evaluation it was concluded that milk solids and cereal based energy bar T2 packaged in metallized PET 
Polyester/ Polyfilm pouches was acceptable up to 135 days of storage at $15 \pm 2^{\circ} \mathrm{C}$. Mridula et al., (2013) observed that the initial average score for appearance and colour, texture, odour, flavour and taste and overall acceptability characteristics of omega-3 rich energy bar sample were 7.2, 7.5, 7.4, 7.8 and 7.7, which decreased after 90 days at ambient storage $\left(25^{\circ} \mathrm{C}\right)$ to $7.1,7.0,7.0,7.0$ and 7.1 , respectively.

Padmashree et al., (2013) reported that the initial score for colour, aroma, taste, texture and overall acceptability characteristics of flaxoat nutty bar within metallized polyester packaging were $8.37,8.33,8.23,8.21$ and 8.41, which decreased after 12 months at ambient storage $\left(3{ }^{\circ} \mathrm{C}\right)$ to $7.15,7.00,7.10$, 7.00 and 7.17 , respectively.

Giri and Mridula (2016) reported that the initial score for appearance and colour, odour, mouthfeel, flavour and taste, sensory texture and overall acceptability characteristics of energy bar utilizing potato extrudates were $7.32,7.45,7.32,7.68,7.45$ and 7.55 , which decreased after 90 days at ambient storage (25 $\left.{ }^{\circ} \mathrm{C}\right)$ to $7.23,7.40,7.29,7.35,7.21$ and 7.24, respectively.

Sobana (2017) observed that the initial average score for appearance, colour, flavour, texture, and taste characteristics of composite sports bar sample were 8.0, 8.2, 8.7, 8.7 and 8.0, which decreased after 90 days at ambient storage $\left(37{ }^{\circ} \mathrm{C}\right)$ to $3.7,2.3,1.9,3.9$ and 1.4 , respectively.

Padmashree et al., (2018) reported that the initial score for colour, aroma, taste, texture and overall acceptability characteristics of choco-quinoa nutri bar within metallized polyester packaging were 8.07, 8.10, 8.20, 8.09 and 8.17, which decreased after 9 months at ambient storage $\left(37^{\circ} \mathrm{C}\right)$ to 7.32 , $7.23,7.32,6.30$ and 6.60 , respectively.
Changes in the physico-chemical characteristics of milk solids (milk protein concentrate) and cereal based energy bar during storage

Physico-chemical changes during storage can have a significant impact on the shelflife of food products. For ascertaining the shelf-life of MCEB, the physico-chemical properties of the products were monitored during the entire storage period. Amongst the physicochemical properties, peroxide value, water activity (aw) and FFA were found to change appreciably during storage (Table 2).

The peroxide value of $\mathrm{T} 1$ and $\mathrm{T} 2$ increased from 0.95 and 0.87 meq of $\mathrm{O}_{2} / \mathrm{Kg}$ fat on zero day to 2.20 and $1.68 \mathrm{meq}$ of $\mathrm{O}_{2} / \mathrm{Kg}$ fat respectively at the end of 150 days of storage at cabinet temperature $\left(15 \pm 2^{\circ} \mathrm{C}\right)$ as shown in Table 2. The changes in the peroxide value among the treatments (T1 and T2) and interaction effect between the treatments and periods were significant for changes in peroxide value. The increase in peroxide value was due to oxygen and water permeability of packaging material (Thakur and Arya, 1990). Padmashree et al., (2013) reported that the initial peroxide value and free fatty acids of the flaxoat nutty bar within metallized polyester packaging increased from 6.99 meq of $\mathrm{O}_{2} / \mathrm{Kg}$ fat and 1.24 per cent oleic acid to $12.68 \mathrm{meq}$ of $\mathrm{O}_{2} / \mathrm{Kg}$ fat and 2.78 per cent oleic acid respectively after 12 months at ambient storage.

The free fatty acids of $\mathrm{T} 1$ and $\mathrm{T} 2$ increased from 0.96 and 1.14 per cent oleic acid on zero day to 1.77 and 1.86 per cent oleic acid respectively at the end of 150 days of storage at cabinet temperature $\left(15 \pm 2^{\circ} \mathrm{C}\right)$ as shown in Table 2 . The changes in the free fatty acids among the treatments (T1 and T2) and interaction effect between the treatments and periods were significant for changes in free fatty acids. The increase in free fatty acids 
was due to degradation products of hydroperoxides which is directly related with RH and moisture content of the products (Sowbhagya and Bhattacharya, 1976). Mridula et al., (2013) observed that the initial free fatty acids of the omega-3 rich energy bar increased from 0.07 per cent oleic acid to 1.45 per cent oleic acid after 90 days at refrigerated storage.

The water activity of $\mathrm{T} 1$ and $\mathrm{T} 2$ increased from 0.483 and 0.495 on zero day to 0.579 and 0.610 respectively at the end of 150 days of storage at cabinet temperature $\left(15 \pm 2^{\circ} \mathrm{C}\right)$. The changes in the water activity among the treatments $\mathrm{T} 1$ and $\mathrm{T} 2$ and the interaction effect between the treatments (T1 and T2) and periods were significant.

This shows that there is significant effect of change in formulation on storage stability of product with respect to water activity. The slight increase of water activity was possibly due to the change in humidity of the surrounding environment (Padmashree et al., 2018). Banach et al., (2016) reported increase in water activity in high protein nutrition bar from 0.48 to 0.50 during storage of 6 weeks.

Rawat and Darappa (2015) observed that the initial peroxide value and free fatty acids of the baked energy bar samples increased from $6.13 \mathrm{meq}$ of $\mathrm{O}_{2} / \mathrm{Kg}$ fat and 5.26 per cent oleic acid to 7.45 meq of $\mathrm{O}_{2} / \mathrm{Kg}$ fat and 8.60 per cent oleic acid respectively after 3 months at ambient storage.

Padmashree et al., (2018) reported that the initial peroxide value, free fatty acids and water activity of the choco-quinoa nutri bar within metallized polyester packaging increased from $5.31 \mathrm{meq}$ of $\mathrm{O}_{2} / \mathrm{Kg}$ fat, 1.32 per cent oleic acid and 0.330 to $12.45 \mathrm{meq}$ of $\mathrm{O}_{2} / \mathrm{Kg}$ fat , 3.21 per cent oleic acid and 0.532 respectively after 9 months at ambient storage.
Changes in the textural characteristics of milk solids (milk protein concentrate) and cereal based energy bar during storage

The changes in textural characteristics of milk solids and cereal based energy bar and control energy bar during storage is shown in Table 3. The hardness of $\mathrm{T} 1$ and $\mathrm{T} 2$ increased from 43.31 and 52.65 on zero day to 120.09 and $167.25 \mathrm{~N}$ respectively at the end of 150 days of storage at cabinet temperature $\left(15 \pm 2^{\circ} \mathrm{C}\right)$. The changes in the hardness scores among the treatments ( $\mathrm{T} 1$ and $\mathrm{T} 2$ ) and the interaction effect between the treatments (T1 and T2) and periods were significant.

The fracturability of control energy bar T1 and milk solids and cereal based energy bar T2 decreased from $1.850 \mathrm{~mm}$ and $1.241 \mathrm{~mm}$ to $0.672 \mathrm{~mm}$ and $0.427 \mathrm{~mm}$ respectively at the end of 150 days of storage at cabinet temperature $\left(15 \pm 2^{\circ} \mathrm{C}\right)$. The changes in the scores of fracturability among the treatments (T1 and T2) and the interaction effect between the treatments and periods were significant $(\mathrm{P}<0.05)$ for fracturability. This shows that there is significant effect of change in formulation on storage stability of product with respect to fracturability. Increase in hardness during storage may be the reason for the decreased in fracturability. McMahon et al., (2009) reported that the initial value of hardness of the high protein nutrition bar increased from $3.4 \mathrm{~N}$ to $15 \mathrm{~N}$ after 37 days of ambient storage.

Pallavi et al., (2015) reported that the initial value of hardness of the fruit and nut cereal bar increased from $180 \mathrm{~N}$ to $240 \mathrm{~N}$ after 90 days of ambient storage $\left(27^{\circ} \mathrm{C}\right)$. Padmashree et al., (2018) reported that the initial value of hardness of the chocoquinoa nutri bar within metallized polyester packaging increased from $43.71 \mathrm{~N}$ to $87.60 \mathrm{~N}$ and fracturability decreased from $1.764 \mathrm{~mm}$ to $1.468 \mathrm{~mm}$ after 9 months at ambient storage $\left(37^{\circ} \mathrm{C}\right)$. 
Table.1 Influence of storage period on sensory characteristics of energy bars

\begin{tabular}{|c|c|c|c|c|c|c|c|c|c|c|c|c|}
\hline \multirow{2}{*}{$\begin{array}{l}\text { Types of } \\
\text { energy bars }\end{array}$} & \multicolumn{11}{|c|}{ Storage period (days) } & \multirow{2}{*}{$\begin{array}{l}\text { Average of } \\
\text { treatments }\end{array}$} \\
\hline & $\mathbf{0}$ & 15 & 30 & 45 & 60 & 75 & 90 & 105 & 120 & 135 & 150 & \\
\hline \multicolumn{13}{|c|}{ Flavour score } \\
\hline $\mathbf{T}_{1}$ & 7.94 & 7.74 & 7.45 & 7.35 & 7.27 & 7.14 & 7.07 & 6.94 & 6.54 & 6.1 & 5.46 & 7.00 \\
\hline $\mathbf{T}_{2}$ & 8.55 & 8.39 & 8.31 & 8.25 & 8.06 & 8.03 & 7.91 & 7.72 & 7.50 & 6.88 & 5.97 & 7.80 \\
\hline Average of periods & 8.24 & 8.07 & 7.88 & 7.80 & 7.66 & 7.59 & 7.49 & 7.33 & 7.02 & 6.49 & 5.72 & \\
\hline \multicolumn{13}{|c|}{$\mathrm{CD}(0.05) \mathrm{T}=0.02 ; \mathrm{P}=0.06 ; \mathrm{T} \times \mathrm{P}=0.08 ; \mathrm{CV} \%=1.74$} \\
\hline \multicolumn{13}{|c|}{ Body \& texture score } \\
\hline $\mathbf{T}_{1}$ & 7.94 & 7.79 & 7.53 & 7.33 & 7.25 & 7.19 & 7.08 & 6.93 & 6.52 & 6.22 & 5.57 & 7.03 \\
\hline $\mathbf{T}_{2}$ & 8.47 & 8.35 & 8.24 & 8.19 & 8.04 & 7.90 & 7.72 & 7.64 & 7.51 & 6.71 & 5.99 & 7.72 \\
\hline Average of periods & 8.21 & 8.07 & 7.89 & 7.76 & 7.65 & 7.54 & 7.40 & 7.28 & 7.02 & 6.47 & 5.78 & \\
\hline \multicolumn{13}{|c|}{$\mathrm{CD}(0.05) \mathrm{T}=0.02 ; \mathrm{P}=0.04 ; \mathrm{T} \times \mathrm{P}=0.06 ; \mathrm{CV} \%=1.48$} \\
\hline \multicolumn{13}{|c|}{ Colour \& appearance score } \\
\hline $\mathbf{T}_{1}$ & 8.17 & 8.14 & 7.84 & 7.74 & 7.63 & 7.52 & 7.24 & 6.85 & 6.34 & 6.16 & 5.32 & 7.18 \\
\hline $\mathbf{T}_{2}$ & 8.53 & 8.36 & 8.25 & 8.15 & 8.07 & 8.00 & 7.93 & 7.77 & 7.55 & 7.08 & 5.98 & 7.82 \\
\hline Average of periods & 8.35 & 8.25 & 8.04 & 7.95 & 7.85 & 7.76 & 7.58 & 7.31 & 6.95 & 6.63 & 5.65 & \\
\hline \multicolumn{13}{|c|}{$\mathrm{CD}(0.05) \mathrm{T}=0.02 ; \mathrm{P}=0.04 ; \mathrm{T} \times \mathrm{P}=0.06 ; \mathrm{CV} \%=1.27$} \\
\hline \multicolumn{13}{|c|}{ Overall acceptability score } \\
\hline $\mathbf{T}_{1}$ & 7.65 & 7.55 & 7.34 & 7.20 & 7.06 & 6.92 & 6.82 & 6.74 & 6.25 & 6.01 & 5.21 & 6.79 \\
\hline $\mathbf{T}_{2}$ & 8.53 & 8.25 & 8.16 & 7.96 & 7.88 & 7.75 & 7.47 & 7.36 & 6.93 & 6.33 & 5.92 & 7.53 \\
\hline Average of periods & 8.09 & 7.90 & 7.75 & 7.58 & 7.47 & 7.33 & 7.15 & 7.05 & 6.59 & 6.12 & 5.57 & \\
\hline
\end{tabular}

$\mathrm{T}_{1}=$ Control energy bar; $\mathrm{T}_{2}=$ Milk solids and cereal based energy bar, Values are mean of three replications 
Table.2 Influence of storage period on physico-chemical characteristics of energy bars

\begin{tabular}{|c|c|c|c|c|c|c|c|c|c|c|c|c|}
\hline \multirow{2}{*}{$\begin{array}{l}\text { Types of } \\
\text { energy bars }\end{array}$} & \multicolumn{11}{|c|}{ Storage period (days) } & \multirow{2}{*}{$\begin{array}{l}\text { Average of } \\
\text { treatments }\end{array}$} \\
\hline & $\mathbf{0}$ & 15 & 30 & 45 & 60 & 75 & 90 & 105 & 120 & 135 & 150 & \\
\hline \multicolumn{13}{|c|}{ Peroxide value (meq of $\mathrm{O}_{2} / \mathrm{Kg}$ fat ) } \\
\hline $\mathbf{T}_{1}$ & 0.95 & 1.09 & 1.30 & 1.52 & 1.57 & 1.65 & 1.72 & 1.76 & 1.82 & 2.06 & 2.20 & 1.60 \\
\hline $\mathbf{T}_{2}$ & 0.87 & 0.93 & 1.02 & 1.10 & 1.18 & 1.30 & 1.39 & 1.49 & 1.55 & 1.61 & 1.68 & 1.28 \\
\hline Average of periods & 0.91 & 1.01 & 1.16 & 1.31 & 1.38 & 1.48 & 1.56 & 1.63 & 1.68 & 1.84 & 1.94 & \\
\hline \multicolumn{13}{|c|}{$\mathrm{CD}(0.05) \mathrm{T}=0.02 ; \mathrm{P}=0.04 ; \mathrm{T} \times \mathrm{P}=0.05 ; \mathrm{CV} \%=2.26$} \\
\hline \multicolumn{13}{|c|}{ Free fatty acids (\% oleic acid) } \\
\hline $\mathbf{T}_{1}$ & 0.96 & 1.03 & 1.08 & 1.15 & 1.24 & 1.36 & 1.44 & 1.51 & 1.60 & 1.64 & 1.77 & 1.34 \\
\hline $\mathbf{T}_{2}$ & 1.14 & 1.21 & 1.27 & 1.35 & 1.46 & 1.49 & 1.54 & 1.59 & 1.64 & 1.75 & 1.86 & 1.48 \\
\hline Average of periods & 1.05 & 1.12 & 1.17 & 1.25 & 1.35 & 1.43 & 1.49 & 1.55 & 1.62 & 1.69 & 1.80 & \\
\hline \multicolumn{13}{|c|}{$\mathrm{CD}(0.05) \mathrm{T}=0.01 ; \mathrm{P}=0.03 ; \mathrm{T} \times \mathrm{P}=0.05 ; \mathrm{CV} \%=1.95$} \\
\hline \multicolumn{13}{|c|}{ Water activity } \\
\hline $\mathbf{T}_{1}$ & 0.483 & 0.488 & 0.496 & 0.508 & 0.512 & 0.523 & 0.532 & 0.541 & 0.556 & 0.569 & 0.579 & 0.526 \\
\hline $\mathbf{T}_{2}$ & 0.495 & 0.509 & 0.521 & 0.524 & 0.538 & 0.553 & 0.572 & 0.588 & 0.597 & 0.609 & 0.610 & 0.556 \\
\hline Average of periods & 0.489 & 0.498 & 0.508 & 0.516 & 0.525 & 0.538 & 0.552 & 0.565 & 0.577 & 0.589 & 0.595 & \\
\hline
\end{tabular}

$\mathrm{T}_{1}=$ Control energy bar,

$\mathrm{T}_{2}=$ Milk solids and cereal based energy bar,

Values are mean of three replications. 
Table.3 Influence of storage period on textural characteristics of energy bar

\begin{tabular}{|c|c|c|c|c|c|c|c|c|c|c|c|c|}
\hline \multirow{2}{*}{$\begin{array}{l}\text { Types of } \\
\text { energy bars }\end{array}$} & \multicolumn{11}{|c|}{ Storage period (days) } & \multirow{2}{*}{$\begin{array}{l}\text { Average of } \\
\text { treatments }\end{array}$} \\
\hline & $\mathbf{0}$ & 15 & 30 & 45 & 60 & 75 & 90 & 105 & 120 & 135 & 150 & \\
\hline \multicolumn{13}{|c|}{ Hardness (N) } \\
\hline $\mathbf{T}_{1}$ & 43.31 & 54.36 & 63.00 & 71.05 & 80.59 & 94.36 & 100.51 & 107.67 & 111.58 & 117.42 & 120.09 & 87.63 \\
\hline $\mathbf{T}_{2}$ & 52.65 & 63.56 & 73.27 & 83.98 & 94.26 & 105.66 & 117.28 & 122.63 & 139.27 & 145.28 & 167.25 & 105.92 \\
\hline Average of periods & 47.98 & 58.96 & 68.14 & 77.51 & 87.43 & 100.01 & 108.89 & 115.15 & 125.43 & 131.35 & 143.67 & \\
\hline \multicolumn{13}{|c|}{$\mathrm{CD}(0.05) \mathrm{T}=0.807 ; \mathrm{P}=1.892 ; \mathrm{T} \times \mathrm{P}=2.676 ; \mathrm{CV} \%=1.68$} \\
\hline \multicolumn{13}{|c|}{ Fracturability (mm) } \\
\hline $\mathbf{T}_{1}$ & 1.850 & 1.693 & 1.491 & 0.957 & 0.884 & 0.808 & 0.784 & 0.749 & 0.718 & 0.689 & 0.673 & 1.027 \\
\hline $\mathbf{T}_{2}$ & 1.241 & 1.144 & 1.095 & 0.953 & 0.918 & 0.878 & 0.798 & 0.747 & 0.629 & 0.531 & 0.427 & 0.851 \\
\hline Average of periods & 1.546 & 1.418 & 1.293 & 0.955 & 0.901 & 0.843 & 0.791 & 0.748 & 0.674 & 0.610 & 0.550 & \\
\hline
\end{tabular}

$\mathrm{T}_{1}=$ Control energy bar; $\mathrm{T}_{2}=$ Milk solids and cereal based energy bar; $\quad$ Values are mean of three replications.

Table.4 Influence of storage period on SPC count of energy bar

\begin{tabular}{|c|c|c|c|c|c|c|c|c|c|c|c|c|}
\hline \multirow{3}{*}{$\begin{array}{l}\text { Types of } \\
\text { energy bars }\end{array}$} & \multicolumn{11}{|c|}{ Storage period (day) } & \multirow{3}{*}{$\begin{array}{c}\text { Average } \\
\text { of treatments }\end{array}$} \\
\hline & \multicolumn{11}{|c|}{ Standard Plate Count $\left(\log _{10} \mathrm{cfu} / \mathrm{g}\right)$} & \\
\hline & $\mathbf{0}$ & 15 & 30 & 45 & 60 & 75 & 90 & 105 & 120 & 135 & 150 & \\
\hline $\mathbf{T}_{2}$ & 1.20 & 1.67 & 1.77 & 1.92 & 2.05 & 2.12 & 2.29 & 2.59 & 2.75 & 2.92 & 3.04 & 2.21 \\
\hline $\begin{array}{l}\text { Average of } \\
\text { periods }\end{array}$ & 1.31 & 1.72 & 1.82 & 1.94 & 2.04 & 2.13 & 2.29 & 2.55 & 2.74 & 2.87 & 3.02 & \\
\hline
\end{tabular}

$\mathrm{T}_{1}=$ Control energy bar;

$\mathrm{T}_{2}=$ Milk solids and cereal based energy bar,

Values are mean of three replications. 
Changes in the microbial quality of milk solids (milk protein concentrate) and cereal based energy bar during storage

Standard Plate Count (SPC) is a collective enumeration of the overall microbiological quality of the product after production and during its storage period.

Standard Plate Count (SPC) gives the idea about the status of MCEB in terms of its microbiological quality during storage. The influence of period of storage at $15 \pm 2^{\circ} \mathrm{C}$ on the standard plate count of stored samples is shown in Table 4.

The Standard plate count $(\log 10 \mathrm{cfu} / \mathrm{g})$ of $\mathrm{T}_{1}$ and $\mathrm{T}_{2}$ increased from 1.42 and 1.20 on zero day to 2.99 and 3.04 respectively at the end of 150 days of storage at cabinet temperature $\left(15 \pm 2^{\circ} \mathrm{C}\right)$ as shown in Table 4 . The changes in the SPC count among the treatments $T_{1}$ and $\mathrm{T}_{2}$ and the interaction effect between the treatments $\left(T_{1}\right.$ and $\left.T_{2}\right)$ and periods were nonsignificant.

This was expected because none of the microorganisms, including bacteria as well as moulds and yeasts, are able to grow in water activity less than 0.70 (Anderson, 2004) and water activity of both experimental samples were below 0.7 throughout the storage.

Farajzadeh and Golmakani (2011) observed that standard plate count of energy bar increased gradually from the initial value of 2.64 to $3.00 \log 10 \mathrm{cfu} / \mathrm{g}$ when stored for 6 months at ambient temperature.

Padmashree et al., (2012) observed that standard plate count of protein rich composite cereal bar increased gradually from the initial value of 1.07 to $2.48 \log 10 \mathrm{cfu} / \mathrm{g}$ when stored for 9 months at ambient temperature. Throughout the storage study yeast and mold count and coliform count were not detected in both experimental samples $\mathrm{T} 1$ and $\mathrm{T} 2$. The milk solids (Milk Protein Concentrate) and cereal based energy bar and control samples were stored at cabinet temperature $\left(15 \pm 2^{\circ} \mathrm{C}\right)$ after packaging into laminates of Metallised Polyethylene Terephthalate (METPET) Polyester/Polyfilm pouches.

All the sensory parameters viz. flavour, colour and appearance, body and texture and overall acceptability scores decreased significantly over a period of 150 days of storage. The peroxide value, free fatty acids and water activity of experimental sample and control increased up to 150 days of storage at cabinet temperature $\left(15 \pm 2^{\circ} \mathrm{C}\right)$.

Textural characteristics viz. hardness increased while the changes in the fracturability among the treatments and the interaction effect between the treatments and periods were significant.

The Standard plate count of both, experimental sample and control, increased during 150 days of storage at cabinet temperature $\left(15 \pm 2^{\circ} \mathrm{C}\right)$. Coliform and yeast and mold count were not detected in both experimental samples throughout the study period.

The overall acceptability score of milk solids based energy bar was below 6.0 on $150^{\text {th }}$ day of storage hence it was concluded that milk protein concentrate based energy bar packaged in laminates of Metallised Polyethylene Terephthalate (METPET) Polyester/Polyfilm pouches was acceptable up to 135 days of storage at $15 \pm 2^{\circ} \mathrm{C}$.

\section{References}

Banach, J. C., Clark, S., and Lamsal, B. P. 2016. Instrumental and sensory texture attributes of high-protein nutrition bars formulated with extruded milk protein concentrate. Journal of Food Science. 81 (5): 1254- 
1262.

Berti, C., Riso, P., Brusamolino, A., and Porrini, M. 2005. Effect on appetite control of minor cereal and pseudocereal products. British Journal of Nutrition. 94 (5): 850858.

Bower, J. A., and Whitten, R. 2000. Sensory characteristics and consumer liking for cereal bar snack foods. Journal of Sensory Studies. 15 (3): 327-345.

Farajzadeh, D., and Golmakani, M. 2011. Formulation and experimental production of energy bar and evaluating its shelf-life and qualitative properties. Journal Military Medicine. 13 (3): 181-187.

Giri, N. A., and Mridula, D. 2016. Development of energy bar utilizing potato extrudates. Asian Journal of Dairy and Food Research. 35 (3): 241-246.

Karam, L., Grossmann, M., and Silva, R. 2001. Oat flour and corn starch mixtures with high content amylopectin production of snacks. Science and Food Technology. 21: 158- 163.

McMahon, D. J., Adams, S. L., and McManus, W. R. 2009. Hardening of High- Protein Nutrition Bars and Sugar/Polyol-Protein Phase Separation. Journal of Food Science. 74 (6): 312-321.

Mridula, D., Singh, K. K., and Barnwal, P. 2013. Development of omega-3 rich energy bar with flaxseed. Journal of Food Science and Technology. 50 (5): 950-957.

Padmashree, A., Negi, N., Haridas, S., Govindaraj, T., Kumar, K. R. A., Semwal, A. D., and Sharma, G. K. 2018. Development and quality evaluation of Choco Quinoa Nutri Bar during storage. Food and Nutrition Sciences. 9 (7): 899.

Padmashree, A., Sharma, G. K., and Govindaraj,
T. 2013. Development and evaluation of shelf stability of flaxoat nutty bar in different packaging materials. Food and Nutrition Sciences. 4 (5): 538.

Padmashree, A., Sharma, G. K., Srihari, K. A., and Bawa, A. S. 2012. Development of shelf stable protein rich composite cereal bar. Journal of Food Science and Technology. 49 (3): 335-341.

Palazzolo, G. 2003. Cereal bars: they're not just for breakfast anymore. Cereal Foods World. 48 (2): 70-77.

Pallavi, B. V., Chetana, R., Ravi, R., and Reddy, S. Y. 2015. Moisture sorption curves of fruit and nut cereal bar prepared with sugar and sugar substitutes. Journal of Food Science and Technology. 52 (3): 16631669.

Rawat, N., and Darappa, I. 2015. Effect of ingredients on rheological, nutritional and quality characteristics of fibre and protein enriched baked energy bars. Journal of Food Science and Technology. 52 (5): 3006-3013.

Sharma, G. K. 2011. Food processing technologies, Technology focus. Bulletin of Defense Research and Development Organisation. 19 (5): 1-12.

Sobana, R. M. 2017. Quality evaluation of millet based composite sports bar. International Journal of Food Science and Nutrition. 2 (4): 65-68.

Sowbhagya, C. M., and Bhattacharya, K. R. 1976. Lipid autoxidation in rice. Journal of Food Science. 41 (5): 1018-1023.

Thakur, B. R., and Arya, S. S. 1990. Packaging requirement and stability of fried wheat snacks. Journal of Food Science and Technology. 27 (2): 76-81.

\section{How to cite this article:}

Karmajitsinh Jagadevsinh Jetavat, Amitkumar Manojbhai Patel and Smitha Balakrishnan. 2020. Sensory, Physico-Chemical, Textural and Microbial Changes in Milk Protein Concentrate and Cereal Based Energy Bar during Storage. Int.J.Curr.Microbiol.App.Sci. 9(07): 697-707. doi: https://doi.org/10.20546/ijcmas.2020.907.080 